\title{
ANALISIS KELAYAKAN USAHA TAMARILLO YOGURT DI INSTITUT BIO SCIENTIA INTERNATIONAL INDONESIA
}

\author{
Reni Mutiarani Saraswati, Rizka Ruth Pratiwi \\ Fakultas Bisnis, Institut Bio Scientia Internasional Indonesia \\ reni.saraswati@i31.ac.id
}

\begin{abstract}
Tamarillo Yogurt is a healthy drink developed by a group of students at the Institut Bio Scientia Internasional Indonesia. After several months of sales trial, the product has received a very good response from customers as well as good sales performance. Based on this, the founder aims to continue expanding their business eventough the feasibility of the business is unknown yet. This research aims to analyze the business feasibility of Tamarillo Yogurt product. There will be two aspects of analysis, first is non-financial aspects such as market and marketing, management and organizational, technical, legal, socio-economic and environmental. The second is financial aspects that will use criteria such as NPV, IRR, Benefit/Cost Ratio and Payback Periods. In addition, the research will analyze whether the business is affected by the changes in cost and benefit of producing the products. The data usedin the research will be based on primary data and secondary data. Based on financial and non-financial aspects, the result of the studyshows that thebusiness is feasible and profitable.
\end{abstract}

Keywords: Aspek Pasar, Aspek Manajemen, Aspek Teknis, Aspek Keuangan, Net Present Value

\section{PENDAHULUAN}

Kewirausahaan memiliki peranan yang penting sebagai penggerak perekonomian suatu negara karena merupakan sektor yang mampu menyerap tenaga kerja lebih banyak dibandingkan dengan sektor lainnya. Di tahun 2018, rasio kewirausahaan di Indonesia telah mencapai 7 persen dari total penduduk Indonesia (Media Indonesia, 2018). Walaupun ada kenaikan persentasi rasio dibandingkan tahun sebelumnya jumlah tersebut relatif masih rendah dibandingkan dengan negara maju yang pada umumnya memiliki rasio kewirausahaan sebanyak 14 persen dari total penduduknya.

Untuk meningkatkan jumlah pelaku kewirausahaan, pemerintah Indonesia mendorong perguruan tinggi untuk turut berperan serta dalam menciptakan wirausaha muda yang memiliki semangat serta keterampilan kewirausahaan dan mampu menciptakan lapangan kerja. InstitutBio Scientia Internasional Indonesia sebagai salah satu institusi pendidikan tinggi di Indonesia yang memfokuskan diri terhadap kewirausahaan terutama dalam industri bio produk telah memiliki kurikulum pendidikan yang menekankan pentingnya memiliki jiwa serta kemampuan kewirausahaan dengan memberikan pengetahuan, pelatihan serta peluang kewirausahaan bagi mahasiswa, baik perorangan ataupun berkelompok. Salah satu kelompok usaha mahasiswa di Institut Bio Scientia Internasional Indonesia yang telah berhasil dalam menciptakan usaha baru yaitu kelompok usaha Tamarillo Yogurt. Usaha ini merupakan bisnis produk minuman kesehatan yogurt dengan bahan dasar terong belanda.

Yogurt adalah minuman dengan rasa yang enak, segar dan menyehatkan karena memiliki kandungan nutrisi yang penting bagi tubuh seperti protein dan kalsium. Seperti halnya yogurt, buah terong belanda juga memberikan manfaat kesehatan karena buah tersebut mengandung nutrisi antioksi dan mineral, diantaranya adalah protein, vitamin A, C, E sodium, potassium, betakaroten, dan zatbesi. Antioksidan yang terdapatdalamterong belanda seperti, likopene, beta karoten, vitamin A, C, dan E mampu melindungi sel tubuh dari berbagai kerusakan yang disebabkan oleh spesies oksigen reaktif, mampu menghambat terjadinya penyakit degeneratif, dan melawan radikal bebas (Nurhidayah S, 2009).

Selain itu, tidak seperti produk yogurt yang pada umumnya menggunakan buah dan 
perasa artifisial, produk yogurt terong belanda ini dibuat dengan menggunakan buahasli, tanpa bahan pengawet dan pewarna.

Alasan lainnya dalam penggunaan buah terong belanda adalah untuk meningkatkan minat serta kecintaan masyarakat Indonesia terhadap buah yang tumbuh di Indonesia, serta menambah variasi minuman yang ada di Indonesia. Produk yogurt berbasis terong belanda ini mulai diproduksi pada awal November 2016 dan dalam kurun waktu empat bulan semenjak awal produksi, produk ini telah menghasilkan penjualan sebanyak 300 botol. Permintaan akan produk ini pun semakin meningkat sejalannya waktu. Melihat respon permintaan yang cukup baik ini membuat kelompok usaha mahasiswa tersebut optimis akan prospek bisnisyang dijalankan. Namun, karena usaha tersebut relatif masih baru, maka diperlukan suatu studi kelayakan usaha.

Tujuan penelitian ini untuk mengetahui apakah usaha tamarillo yogurt ini menghasilkan keuntungan yang diharapkan dan apakah layak untuk dijalankan dan dilanjutkan.

\section{TINJAUAN PUSTAKA}

Studi kelayakan adalah suatu kegiatan yang mempelajari secara mendalam tentang suatu usaha bisnis yang akan dilakukandengan tujuan untuk menentukan layak atau tidak usaha tersebut untuk dijalankan (Kasmir dan Jakfar 2012). Dalam hal ini, mempelajari secara mendalam berarti meneliti secara sungguh-sungguh data dan informasi, selanjutnya diukur, dihitung dan dianalisis dengan menggunakan metode tertentu (Purwana dan Hidayat, 2016).

Pengertian lainnya yaitu bahwa studi kelayakan bisnis adalah penelitian yang menyangkut berbagai aspek baik itu aspek hukum, aspek keuangan, aspek sosial ekonomi dan budaya, aspek pasar dan pemasaran, aspek perilaku konsumen, aspek teknis dan teknologi, aspek sumber daya manusia dan oganisasi, dimana itu semua digunakan untuk dasar penelitian studi kelayakan dan hasilnya digunakan untuk mengambil keputusan apakah suatu proyek bisnis dapat dikerjakan atau ditunda dan bahkan tidak dijalankan (Sunyoto, 2014)

Studi kelayakan bisnis penting untuk dilaksanakan baik pada usaha yang baru maupun kepada perluasan atau mengembangan dari usaha yang telah ada (Sunyoto, 2014). Hal ini berguna untuk untuk mengantisipasi dan meminimalisir kegagalan atau kerugian suatu usaha. Misalnya untuk menghindari penanaman modal yang terlalu besar atau pemborosan terhadap penggunaan sumber daya dan sumber dana. Keuntungan lainnya yaitu untuk mempermudah pelaku usaha dalam melakukan perencanaan, pelaksanaan, pengawasan serta pengendalian usaha yang dijalankan dengan benar dan tepat.

Selain itu, adanya persaingan bisnis, situasi pasar yang tidak menentu serta kendala bisnis lainnya juga menjadi faktor-faktor yang mendukung untuk melakukan studi kelayakan sebelum menjalankan sebuah projek atau usaha.

\section{Aspek-aspek Non-Finansial}

Terdapat beberapa aspek non-finansial yang dapat dikaji dalam melakukan studi kelayakan usaha. Dalam penelitian ini, aspek yang akan dianalisis yaitu aspek pasar dan pemasaran, aspek manajemen dan organisasi, aspek hukum, aspek teknis, aspek sosial, ekonomi dan lingkungan. Berikut ini penjelasan dari aspek - aspek yang telah disebutkan di atas.

Dalam aspek pasar dan pemasaran, halhal yang dianalisa adalah variabel-variabel yang meliputi jumlah permintaan, penawaran, harga jual produk, pemasaran serta persaingan yang akan mempengaruhi sukses tidaknya usaha produk tamarillo yohgurt tersebut. Menurut Purwana dan Hidayat (2016), aspek pasar dan pemasaran dilakukan untuk meninjau apakah usaha tersebut memiliki peluang pasar yang diinginkan atau tidak.

Aspek manajemen merupakan pencapaian sasaran - sasaran organisasi dengancara yang efektif dan efisien melalui perencanaan, pengorganisasian, kepemimpinan dan pengendalian sumber daya organisasi (Sulastri, 2016). Aspek ini meliputi hal-hal yang berkaitan denganpara pengelola usaha, struktur organisasi dan bentuk organisasi sesuai dengan bentuk tujuan usahanya (Purwana dan Hidayat, 2016).

Aspek legal atau hukum adalah aspek yang menyangkut semua legalitas rencana bisnis yang akan dilaksanakan yang meliputi ketentuan hukum yang berlaku diantaranya Izin lokasi, akte pendirian perusahaan dari notaris setempat $\mathrm{PT} / \mathrm{CV}$ atau berbentuk badan hukum lainnya, NPWP (Nomor Pokok Wajib Pajak), surat tanda daftar perusahaan, surat izin tempat usaha dari pemda setempat, surat tanda rekanan dari pemda setempat dan SIUP setempat (Sulastri, 2016).

Aspek teknis atau operasional adalah aspek yang menganalisis variable - variabel seperti 
lokasi usaha, layout gedung, layout ruangan, mesin, peralatan sampai kepada usaha perluasan selanjutnya (Purwana dan Hidayat, 2016). Selain itu, fasilitas produksi, bahan baku, jumlah tenaga kerja, teknologi yang digunakan, proses produksi, produksi optimum, pengemasan, serta penyimpanan juga merupakan kriteria yang penting dalam mengkaji aspek teknis.

Aspek sosial ekonomi dan lingkungan meninjau seberapa besar pengaruh yang ditimbulkan jika proyek tersebut dijalankan. Pengaruh tersebut terutama terhadap ekonomi secara luas, dampak sosial terhadap masyarakat dan dampak terhadap lingkungan secara keseluruhan (Purwana dan Hidayat, 2016).

\section{Aspek Finansial}

Keuangan merupakan salah satu fungsi bisnis yang bertujuan untuk membuat keputusan investasi, pendanaan dan dividen (Sulastri, 2016). Dalam penelitian ini, analisa keuangan perlu dilakukan untuk mengetahui apakah investasi dari usaha tamarillo yogurt ini dapat menghasilkan keuntungan yang sesuai dalam jangka waktu tertentu.

Purwana dan Hidayat (2016) berpendapat bahwa suatu bisnis dapat dikatakan layak apabila jenis usaha tersebut mampu memberikan laba usaha yang memadai kepada pihak investor atau pengusaha yang menjalankan usaha. Pembahasan dalam aspek ini meliputi sumber-sumber dana, perkiraan investasi, biaya operasioanl, perkiraan pendapatan, laporan keuanagan dan rasio-rasio keuangan (Sunyoto, 2014). Untuk dapat menentukan apakah suatu proyek investasi dapat dikatakan layak diperlukan teknik- teknik kriteria penilaian investasi yang didasarkan pada estimasi aliran kas proyek yang bersangkutan. Kriteria yang biasa digunakan untuk menentukan kelayakan suatu usaha atau investasi secara umum adalah Net Present Value (NPV), Internal rate of Return (IRR), Benefit and Cost serta Payback Periods.

Pertama, Net Present Value (NPV) adalah analisis manfaat finansial yang digunakan untuk mengukur kelayakan suatu usaha dengan rumus sebagai berikut:

$$
\mathrm{NPV}=\sum_{t=0}^{n} \frac{B_{t}-C_{t}}{(1+i)^{t}}
$$

\section{Di mana:}

$\mathrm{B}=$ manfaatyangdiperoleh setiap tahun

$\mathrm{Ct}=$ biayayangdikeluarkan setiap tahun $\mathrm{n}=$ jumlah tahun

$\mathrm{i}=$ tingkat bunga(diskonto)

Kriteria investasi berdasarkan NPV yaitu:

- $\mathrm{NPV}=0$, artinya proyek tersebut mampu memberikan tingkat pengembalian sebesar modal sosial Opportunities Cost faktor produksi normal. Dengan kata lain, proyek tersebut tidak untungmaupun rugi.

NPV>

0 ,artinyasuatuproyekdinyatakanmenguntungk andandapat dilaksanakan.

- $\mathrm{NPV}<$

0,artinyaproyektersebuttidakmenghasilkannila ibiayayang dipergunakan,atau dengan kata lain proyek tersebutmerugikan dan sebaiknyatidak dilaksanakan.

Kedua, Internal Rate of Return (IRR) adalah analisis manfaat finansial yang memperhitungkan tingkat pengembalian dari suatu investasi. IRR memperhitungkan tingkat suku bunga terkait nilai sekarang investasi dibandingkan dengan niai sekarang penerimaan kas bersih di masa mendatang (Purwanto \& Hidayat, 2016). Rumus IRR adalah sebagai berikut:

$$
\mathrm{IRR}=i+\frac{N P V}{N P V-N P V^{\prime}}\left(i^{\prime}-i\right)
$$

Dimana:

$\mathrm{i}=$ Discount rate yang menghasilkan NPV positif

i'= Discount rate yang menghasilkan NPV negatif NPV = NPV yang bernilai positif

$\mathrm{NPV}^{\prime}=\mathrm{NPV}$ yang bernilai negatif

Ketiga, Benefit dan Cost Ratio (B/C Ratio) atau disebut juga Profitability Index (PI) merupakan ratio aktifitas dari jumlah sekarang penerimaan bersih dengan nilai sekarang pengeluaran investasi selama umur investasi (Purwana dan Hidayat, 2016). B/C ratio ini menunjukkan gambaran berapa kali lipat manfaat yang diperoleh dari biaya yang dikeluarkan. Rumus B/C Ratio adalah usahasebagai berikut:

$$
\text { Net } \mathrm{B} / \mathrm{C}=\frac{\sum_{t=0}^{n} \frac{B_{t}-C_{t}}{(1-i)^{t}}}{\sum_{t=0}^{n} \frac{B_{t}-C_{t}}{(1-i)^{t}}} \quad \text { Dimana } \frac{\left(B_{t}-C_{t}>0\right)}{\left(B_{t}-C_{t}<0\right)}
$$

Dimana:

$\mathrm{B}=$ manfaatyangdiperoleh setiap tahun

$\mathrm{Ct}=$ biayayangdikeluarkan setiap tahun

$\mathrm{n}=$ jumlah tahun

$\mathrm{i}=$ tingkat bunga(diskonto) 
Kriteria investasi berdasarkan Net B/Crasio adalah:

- Net $\mathrm{B} / \mathrm{C}=1$, maka $\mathrm{NPV}=0$, artinya proyek tidak untung ataupun rugi

- Net B/C>1, maka NPV >0, artinya proyek tersebut menguntungkan

- Net $\mathrm{B} / \mathrm{C}<1$, maka NPV $<0$, artinya proyek tersebut merugikan

Keempat, Payback Periodsadalah jangka waktu tertentu yang menunjukkan terjadinya arus penerimaan kumulatif sama dengan jumlah investasi dalam bentuk present value (Purwana dan Hidayat, 2016). Rumus Payback Periods adalah sebagai berikut:

$$
\text { Payback Period }(P P)=\frac{\text { Investasi }}{\text { Kas Bersih / Tahun }}
$$

Semakin kecil periode waktu pengembaliannya, semakin cepat proses pengembalian suatu investasi (Purwana dan Hidayat, 2016).

Analisis sensitifitas kelayakan usaha dapat dilakukan dengan mengumpulkan data terkait kelayakan usaha yogurt terong belanda tersebut, sehingga apabila analisa sensitivas menyatakan bahwa usaha ini tidak layak, maka perlu dilakukan perhitungan ulang untuk mengetahui besaran biaya dan manfaat yang layak. Sebaliknya apabila analisis sensitivitas menunjukkan bahwa usaha ini layak, maka usaha bisa dilaksanakan karena dapat memberikan keuntungan bagi yang berinvestasi.

Dalam penelitian ini, analisis kepekaan digunakan apabila terjadi perubahan pada kenaikan harga input atau bahan baku dan penurunan jumlah penjualan. Data primer mengenai analisis kelayakan investasi aktivitas ekonomi, apakah ada perubahan dan apabila terjadi kesalahan atau adanya perubahan di dalam perhitungan biaya atau manfaat.

\section{METODE PENELITIAN}

Penelitian ini menggunakan data primer dan data sekunder. Data primer merupakan data hasil wawancara dengan pihak- pihak terkait dan observasi langsungdilapangan. Data sekunder diperoleh dari hasil laporan perusahaan,artikel dan studiliteratur. Penelitian ini dilakukan di Institut Bio Scientia Internasional Indonesia selama 1 (satu) tahun yang mencakup dua tahap. Tahap pertama diutamakan kepada penelitian terhadap kelayakan non finansial yang mencakup langkah-langkah sebagai berikut:

1. Analisis aspek pasar dan pemasaran

2. Analisis aspek manajemen dan organisasi

3. Analisis aspek hukum

4. Analisis aspek teknis

5. Analisis aspeksosial, ekonomi dan lingkungan

Untuk tahap diatas, peneliti akan mengumpulkan data berdasarkan observasi lapangan serta wawancara dengan pelaku usaha.

Tahap kedua dari penelitian ini adalah analisisi kelayakan finansial, di mana peneliti akan mengumpulkan data secara kuantitatif serta melakukan perhitungan mengenai Net Present Value (NPV), InternalRate of Return (IRR), Benefit/Cost(NetB/C), Payback Periods dan sensitivitas usaha.

\section{HASIL PENELITIAN\& PEMBAHASAN}

Dalam penelitian ini, analisis pasar meninjau perihal produk, pangsa pasar, penetapan harga jual serta strategi pemasaran.

\section{Analisis Aspek Pasar dan Pemasaran}

Pembahasan yang pertama adalah bentuk dari produk usaha. Produk Tamarillo Yogurt ini adalah produk yogurt dengan menggunakan bahan dasar buah terong belanda. Produk ini memiliki beberapa keunggulan yaitu memiliki rasa yang enak, segar, dan dibuat tanpa bahan pengawet, pemanis serta pewarna buatan. Keunggulan yang kedua yaitu bahwa produk ini memiliki manfaat bagi kesehatan tubuh. Yang ketiga, produk ini cukup unik karena merupakan satusatunya produk minuman yogurt berbasis terong belanda yang ada di Indonesia pada saat ini. Keunggulan yang keempat yaitu adanya trend dan kebutuhan konsumen akan minuman sehat yang memberikan suatu peluang bagi pelaku usaha untuk memenuhi permintaan pasar terhadap produk minuman yang menyehatkan.

Selain cita rasa dari produk itu sendiri, kemasan produk ini pun perlu diperhatikan karena akan mempengaruhi minat pelanggan dalam memilih produk minuman. Dalam hal ini, produk Tamarillo Yogurt telah mengalami perubahan kemasan 
sebanyak dua kali, dimana bentuk kemasan yang kedua lebih menarik dibandingkan dengan kemasan sebelumnya.

Tabel 1.

Perbandingan harga minuman yogurt terong belanda dengan beberapa minuman yogurt yang ada di pasaran Indonesia.

\begin{tabular}{|l|c|}
\hline \multicolumn{1}{|c|}{ Kisaran Harga Produk Minuman Yogurt } & $\begin{array}{c}\text { Harga per } \\
100 \mathrm{ml}\end{array}$ \\
\hline $\begin{array}{l}\text { Cimory Yogurt Drink Passion Fruit (250 } \\
\text { Biokul Mango Yogurt Drink (150 ml) }\end{array}$ & 3960 \\
Biokul Strawberry Yogurt Drink (150 ml) & 6200 \\
Heavenly Blush (180 ml) & 6267 \\
Yummy Yofit Probiotic Orange Yogurt & 7000 \\
(180 ml) & 5444 \\
Kin Bulgarian Yogurt Drink (200 ml) & 4950 \\
Tamarillo Yogurt (250 ml) & 6000 \\
\hline
\end{tabular}

Sumber: diolah dari data primer (2018)

Dalam hal penetapan harga, tim usaha produk Tamarillo Yogurt telah menetapkan harga produk sebesar Rp. 15.000 per botol dengan kemasan isi $250 \mathrm{ml}$. Harga tersebut ditetapkan berdasarkan analisis biaya produksi dengan jumlah produksi yang belum maksimalserta berdasarkan asumsi bahwa produk ini memiliki keunggulan sebagai satusatunya produk minuman yogurt yang berbahan dasar terong belanda di Indonesia pada saat ini. Tabel. 1 ini memberikan gambaran perbandingan harga produk Tamarillo Yogurt dengan produk serupa di Indonesia pada tahun 2018.

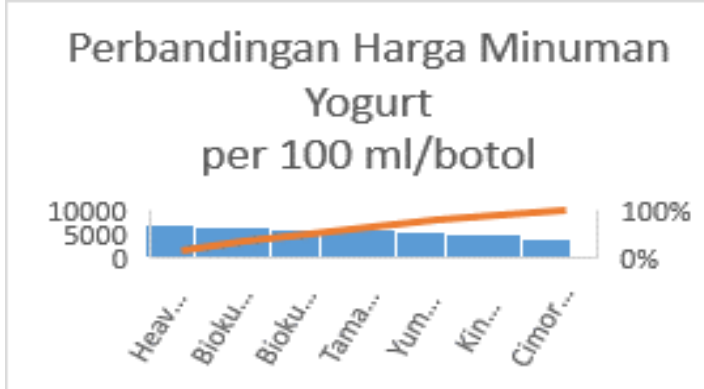

Gambar 1. Pareto diagram perbandingan harga minuman yogurt terong belanda

Produk minuman yogurt yang dijual di supermarket berkisar antara Rp. 8.000 sampai dengan Rp. 15.000 per botol, dengan kemasan isi $150 \mathrm{ml}$ sampai dengan $250 \mathrm{ml}$ per botol. Produk-produk tersebut diproduksi secara lokal atau bahkan di impor dari luar negeri.

Berdasarkan pareto diagram dalam gambar 1, harga yang telah ditetapkan untuk produk ini termasuk ke dalam kisaran harga yang tidak terlalu tinggi maupun terlalu rendah dibandingkan dengan produk serupa di pasaran.

Dalam hal pemasaran, produk ini sudah mulai dikenal terutama di kalangan mahasiswa Institut Bio Scientia Internasional Indonesia serta sudah mulai merambah konsumen dari berbagai kalangan di luar kampus. Strategi pemasaran yang dilakukan diantaranya dengan menjual di toko yang telah disediakan di kampus Institut Bio Scientia Internasional Indonesia, toko online, bazaar dan dijual melalui pengecer. Sedangkan kegiatan promosi dilakukan dengan membagikan sampel produk pada saat pameran dan seminar produk baik di Jakarta maupun di luar kota Jakarta. Promosi lainnya yaitu dengan memanfaatkan media elektronik seperti internet.

2. Analisis Aspek Manajemen dan Organisasi

Pelopor usaha dari bisnis produk Tamarillo Yogurt terdiri dari tiga orang mahasiswa. Ketiganya terlibat penuh dalam mengelola keseluruhan kegiatan usaha dan pada saat ini memperkerjakan satu orang pekerja lapangan. Ketiga pemilik usaha memiliki tugas yang beragam dari mulai mencari bahan mentah sampai dengan proses produksi dan pemasaran. Tim usaha ini belum memiliki struktur organisasi yang membagi wewenang serta tanggung jawab yang jelas. Hal ini disebabkan karena ketiga mahasiswa tersebut masih mencari struktur organisasi yang tepat bagi kelangsungan usahanya. Pekerja lapangan memiliki tugas dalam memproduksi produk, dari mulai mencari bahan mentah sampai dengan pengemasan.

\section{Aspek Teknis}

Lokasi proyek usaha berada di kampus Institut Bio Scientia Internasional Indonesia dimana terdapat fasilitas laboratorium dengan peralatan yang sangat memadai untuk memproduksi produk dari usaha ini. Pada saat ini, tim produksi mampu membuat produk sebanyak kurang lebih 50 
dalam sebulan. Jumlah tersebut terbilang rendah karena tenaga kerja yang tersedia tidak cukup untuk memproduksi dalam kapasitas maksimum. Tetapi dengan penambahan jumlah tenaga kerja yang memadai, produksi Tamarillo Yogurt dapat ditingkatkan hingga mencapai kapasitas maksimum.Penambahan tenaga kerja juga merupakan hal yang telah direncanakan oleh tim, terutama,apabila ada kenaikan permintaan produk dalam jumlah tertentu. Hal ini merupakan bagian dari strategi bisnis yangdilaksanakan oleh tim yang mencakup perencananaan kegiatan produksi serta pemasaran dalam jangka pendek maupun jangka panjang.

\section{Aspek Hukum}

Salah satu keunggulan dari produk ini adalah terciptanya suatu produk minuman yogurt berbahan dasar terong belanda yang memiliki kandungan yang menyehatkan serta belum ada produk serupa di pasaran Indonesia. Sehingga produk ini layak untuk melakukan pengajuan HKI agar mendapatkan perlindungan untuk hasil karya intelektualitas tersebut. Pengajuan HKI ini telah menjadi bagian dari rencana tim usaha terkait aspek hukum.

Selain itu, rencana lainnya adalah menetapkan suatu badan hukum yang sesuai untuk kelangsungan usaha ini. Bentuk perusahaan yang sesuai untuk industri minuman yogurt ini adalah Persekutuan Komanditer (CV) dengan alasan modal investasi yang dibutuhkan untuk usaha ini relatif kecil. Hal lainnya yang perlu dipertimbangkan yaitu mendaftarkan BPOM dan sertifikasi halal agar produk Tamarillo Yogurt dapat diterima oleh berbagai kalangan masyarakat serta memberikan kepastian dan informasi terkait aspek kesehatan serta kandungan produk kepada konsumen.

\section{Aspek Sosial Ekonomi dan Lingkungan}

Dalam aspek sosial, ekonomi dan lingkungan, produk dari usaha ini memiliki manfaat bagi masyarakat Indonesia pada umumya. Pertama, produk ini telah manambah varian minuman sehat di pasaran Indonesia. Kedua, kebutuhan akan bahan dasar produk ini, dapat meningkatkan pendapatan petani terong belanda di Indonesia. Ketiga, baik dalam produksi maupun pemasarannya, usaha ini turut menambah lapangan pekerjaan yang bisa menaikkan pendapatan para pekerja serta tentunya menambah potensi meningkatnyaPDB Indonesia. Keempat dan tak kalah pentingnya yaitu menambah wawasan bagi pelaku UMKM lainnya dalam melakukan usaha di bidang serupa.

\section{Aspek Keuangan}

Penelitian ini mengkaji aspek keuangan dengan menggunakan kriteria seperti Net Present Value, (NPV), Interest Rate of Return (IRR), Benefit/Cost Ratio dan Payback Periodsdari usaha produk minuman Tamarillo Yogurt yang diproyeksikan selama 5 tahun kedepan. Selain itu, penelitian ini juga akan menganalisis kelayakan usaha ditinjau dari sensitivitas usaha, apabila terjadi perubahan pada faktor - faktor yang dapat mempengaruhi manfaat dan biaya.

Dalam usaha, salah satu faktor yang mempengaruhi besar kecilnya suatu investasi adalah biaya produksi. Dalam biaya produksi terdapat biaya bahan baku, biaya ini merupakan salah satu aspek penting dalam perhitungan produksi suatu usaha karena akan mempengaruhi jumlah serta harga dari produk tersebut. Untuk memproduksi Tamarillo Yogurt dibutuhkan bahan baku seperti buah terong belanda, susu ultra rendah lemak, yogurt, gula cair, bahan karagenan, packaging botol dan sticker.

Berdasarkan perhitungan table di bawah ini, apabila tim produksi membuat produk sebanyak 4000 botol maka jumlah biaya yang dikeluarkan adalah $\mathrm{Rp} 18.200 .000$, dimana biaya produksi Tamarillo Yogurt per satuan unit adalah Rp. 4,550. Selain itu, terdapat biaya tenaga kerja, dimana pada saat ini tim usaha hanya memperkerjakan satu pekerja lapangan yang mampu memproduksi produk paling banyak 50 botol dalam satu hari kerja.

Biaya lainya adalah biaya pengembangan produk, promosi, listrik, transportasi dan distribusi, sewa tempat dan peralatan, dan biaya bunga pinjaman yaitu $15 \%$ per tahun. Selain itu, adapula biaya perijinan, pembentukan badan usaha dan sertifikasi yang akan dilakukan di tahun pertama pembentukan usaha. Berdasarkan data yang diolah, hasil Net Present Value (NPV) usaha minuman yogurt berbasis terong 
belanda ini adalah sebesar Rp. 1,371,150,576 dimana NPV > 0. Dari hasil ini dapat disimpulkan bahwa hasil bersih (net benefit) yang diterima selama 5 tahun mendatang menunjukkan angka positif, sehingga usaha ini dinyatakan menguntungkan dan layak untuk dijalankan.

\section{Tabel 2. Total biaya produksi}

\begin{tabular}{|c|l|r|l|r|r|}
\hline \multicolumn{6}{|c|}{ Biaya Produksi Tamarillo Yogurt } \\
\hline No & \multicolumn{1}{|c|}{ Uraian } & \multicolumn{2}{|c|}{ Quantity } & Harga & Jumlah \\
\hline & $\begin{array}{l}\text { Buah Terong } \\
\text { Belanda }\end{array}$ & 60 & $\mathrm{~kg}$ & 15,000 & 900,000 \\
\hline & $\begin{array}{l}\text { Susu Ultra } \\
\text { Rendah Lemak }\end{array}$ & 200 & $\mathrm{ltr}$ & 15,000 & $3,000,000$ \\
\hline 3 & Yogurt 200 ml & 200 & botol & 12,500 & $2,500,000$ \\
\hline & $\begin{array}{l}\text { Gula Cair @ } \\
\text { 250 ml }\end{array}$ & 24 & botol & 12,500 & 300,000 \\
\hline 5 & $\begin{array}{l}\text { Bahan } \\
\text { Karagenan }\end{array}$ & 10 & $\mathrm{~kg}$ & 150,000 & $1,500,000$ \\
\hline 6 & $\begin{array}{l}\text { Packaging } \\
\text { botol 250 ml }\end{array}$ & 4,000 & botol & 2,500 & $10,000,000$ \\
\hline & \multicolumn{7}{|l}{} & $18,200,000$ \\
\hline
\end{tabular}

Sumber: diolah dari data primer (2018)

Nilai Internal Rate of Return (IRR) adalah sebesar $2.69 \%$ merupakan hasil yang positifdan lebih besar dibandingkan dengan nilai suku bunga yaitu $15 \%$ per tahun. Hasil ini menunjukkan bahwa kelayakan usaha produk Tamarillo Yogurt dinyatakan menguntungkan dan layak dilanjutkan. Metode Benefit dan Cost Ratio dalam usaha kelayakan minuman yogurt ini digunakan sebagai evaluasi awal dari perencanaan investasi dimana hasil $\mathrm{B} / \mathrm{C}$ ratio nya adalah sebesar 24.57. Hasil tersebut menunjukkan bahwa $\mathrm{B} / \mathrm{C}$ ratio $>1$, artinya perbandingan benefit proyek jauh lebih besar dari biaya yang dibutuhkan, oleh karena itu usaha minumam yogurt ini layak untuk dijalankan.
Break Even Point atau disebut juga payback periods dari usaha ini adalah 1.4 tahun, menunjukkan bahwa usaha ini dapat menghasilkan pengambalian modal dalam waktu yang relatif cepat.

Pada tabel menunjukkan proyeksi laba rugi serta analisis usaha dari produk Tamarillo Yogurt. Pembahasan yang terakhir yaitu mengenai analisis sensitivitas kelayakan usaha Tamarillo Yogurt yang dilakukan untuk melihat apakah ada dampak terhadap usaha tersebut apabila ada perubahan di dalam perhitungan biaya atau manfaat. Analisis ini perlu dilakukan karena dalam berinvestasi, perhitungan didasarkan pada proyek - proyek yang mengandung ketidakpastian tentang apa yang akan terjadi diwaktu yang akan datang.

Dalam penelitian ini, analisis sensitivitas dilakukan dengan menghitung IRR, NPV, B/C ratio dan payback period pada beberapa skenario perubahan harga input atau bahan pokok serta harga jual produk. Analisis sensitivitas berdasarkan table 5 menunjukkan bahwa:

- peningkatan harga bahan baku dan input sebersar 10 persen dan menurunkan harga jual sebesar 10 persen masih menunjukkan NPV lebih besar daripada nol. Hal ini menunjukkan proyek tersebut masih tetap layak untuk dijalankan.

- peningkatan harga bahan baku dan input sebesar 20 persen dan menurunkan harga jual sampai sebesar 20 persen masih menunjukkan NPV lebih besar daripada nol. Hal ini menunjukkan proyek tersebut masih tetap layak untuk dijalankan. 
Tabel 3. Proyeksi Laba Rugi Usaha

\begin{tabular}{|c|c|c|c|c|c|c|c|}
\hline \multirow{2}{*}{ No } & \multirow{2}{*}{ URAIAN } & \multicolumn{5}{|c|}{ YEARS } & \multirow[b]{2}{*}{ Jumlah } \\
\hline & & 1 & 2 & 3 & 4 & 5 & \\
\hline & DANA INTESTASI & & & & & & \\
\hline & & & & & & & \\
\hline & & $-\mathrm{Rp} 70,000,000$ & Rp $121,408,000$ & Rp266,524,000 & Rp567,556,000 & Rpl,180,420,000 & \\
\hline & Saldo Kas & Rp $70,000,000$ & Rp $121,408,000$ & Rp266,524,000 & Rp567,556,000 & Rp1,180,420,000 & Rpl, $789,684,000$ \\
\hline \multirow[t]{4}{*}{1} & PENERIMAAN & & & & & & \\
\hline & Produksi (Botol $250 \mathrm{ml}$ ) & 14,400 & 28,800 & 57,600 & 115,200 & 115,200 & Rp331,200 \\
\hline & Harga Jual & Rp15,000 & Rp15,000 & Rp15,000 & Rp15,000 & Rp15,000 & Rp75,000 \\
\hline & Jumlah Penerimaan & Rp216,000,000 & Rpt32,000,000 & Rps64,000,000 & Rpl,728,000,000 & Rpl, $728,000,000$ & $\mathrm{Rp} 4,968,000,000$ \\
\hline \multirow[t]{11}{*}{2} & PENGELUARAN & & & & & & \\
\hline & Biaya Produksi & $65,520,000$ & $131,040,000$ & $262,080,000$ & $524,160,000$ & $524,160,000$ & Rp1,506,960,000 \\
\hline & Biaya Tenaga Kerja & $52,000,000$ & $104,000,000$ & $208,000,000$ & $416,000,000$ & $416,000,000$ & Rpl,196,000,000 \\
\hline & Biaya Listrik & $3,600,000$ & $7,200,000$ & $14,400,000$ & $28,800,000$ & $28,800,000$ & Rp $\$ 2,800,000$ \\
\hline & Biaya Promosi & $2,000,000$ & $4,000,000$ & $8,000,000$ & $16,000,000$ & $16,000,000$ & Rp46,000,000 \\
\hline & Biaya Transportasi \& Distribusi & $5,760,000$ & $11,520,000$ & $23,040,000$ & $46,080,000$ & $46,080,000$ & Rp132,480,000 \\
\hline & Biaya Sewa tempat dan peralatan & $12,000,000$ & $12,000,000$ & $12,000,000$ & $12,000,000$ & $12,000,000$ & Rp $60,000,000$ \\
\hline & Biaya Pengembangan Produk & $18,000,000$ & Rp1,000,000 & $\mathrm{Rp} 2,000,000$ & $\mathrm{Rp} 4,000,000$ & $\mathrm{Rp} 8,000,000$ & Rp33,000,000 \\
\hline & Biaya Perijinan, badan usaha, sertifikasi & $7,000,000$ & - & $\dot{.}$ & - & - & $7,000,000$ \\
\hline & Biaya Bunga Pinjaman $15 \%$ Thn & Rp10,500,000 & Rp10,500,000 & Rp10,500,000 & Rp10,500,000 & Rp10,500,000 & $\mathrm{Rp} 52,500,000$ \\
\hline & Jumlah Pengeluaran & $158,880,000$ & $270,760,000$ & $529,520,000$ & $1,047,040,000$ & $1,051,040,000$ & $3,057,240,000$ \\
\hline \multirow[t]{2}{*}{3} & Laba Sebelum Pajak & Rp57,120,000 & Rpl61,240,000 & Rp334,480,000 & Rp680,960,000 & Rp676,960,000 & Rpl,910,760,000 \\
\hline & $\operatorname{Tax} 10 \%$ & Rp5,712,000 & Rpl6,124,000 & Rp33,448,000 & Rp68,096,000 & Rp67,696,000 & Rp191,076,000 \\
\hline 4 & Laba setelah Pajak & Rp51,408,000 & Rpl45,116,000 & Rp301,032,000 & Rp612,864,000 & Rp609,264,000 & Rpl, $910,760,000$ \\
\hline
\end{tabular}

Sumber: diolah dari data primer (2018)

Tabel 4. Analisa Usaha

\begin{tabular}{|c|r|r|r|r|}
\hline Tahun & \multicolumn{1}{|c|}{ PV 6\% } & \multicolumn{1}{|c|}{ Net B/C } & IRR & Payback Period \\
\hline 1 & Rp48,498,307 & 0.73 & $\mathbf{2 . 6 9}$ & $\mathbf{1 . 4}$ \\
\hline 2 & Rp129,153,240 & 2.07 & & \\
\hline 3 & Rp252,746,467 & 4.30 & & \\
\hline 4 & Rp485,449,574 & 8.76 & & \\
\hline 5 & Rp455,302,987 & 8.70 & & \\
\hline Total NPV & Rp1,371,150,576 & $\mathbf{2 4 . 5 7}$ & & \\
\hline
\end{tabular}

Sumber: diolah dari data primer (2018)

Tabel 5. Skenario Investasi berdasarkan bahan baku dan harga jual

\begin{tabular}{|l|r|r|r|}
\hline \multirow{2}{*}{ Skenario } & \multicolumn{2}{|c|}{ Kriteria Investasi } \\
\cline { 2 - 4 } & \multicolumn{1}{|c|}{ NPV } & Net B/C & Payback Period \\
\hline Kenaikan bahan baku dan input 10\% & $1,262,667,146$ & 22.63 & 1.5 \\
\hline Kenaikan bahan baku dan input 20\% & $1,154,183,717$ & 20.69 & 1.8 \\
\hline Penurunan harga jual 10\% & $1,013,512,896$ & 18.18 & 2.2 \\
\hline Penurunan harga jual 20\% & $6,555,875,216$ & 11.79 & 5.6 \\
\hline
\end{tabular}

Sumber: diolah dari data primer (2018) 


\section{KESIMPULAN}

Berdasarkan hasil penelitian dan pembahasan terkait aspek non finansial dapat disimpulkan hal-hal sebagai berikut:

- Analisis aspek pasar dan pemasaran menunjukkan bahwa produk Tamarillo Yogurt ini memiliki keunggulan sebagai produk yang unik dan menyehatkan serta memiliki pangsa pasar yang jelas. Selain itu, produk ini dijual dengan harga yang terjangkau dan dipasarkan dengan menggunakan berbagai metode pemasaran yang cukup baik.

- Analisis aspek manajemen dan organisasi menunjukkan bahwa usaha ini telah melakukan perencanaan dan manajemen organisasi serta sumber daya manusia, hanya saja masih kurang efektif dan maksimal.

- Analisis aspek teknis atau operasional menunjukkan bahwa usaha ini masih membutuhkan penyesuaian untuk memaksimalkan kapasitas produksinya sehingga dapat lebih menguntungukan.

- Analisis aspek hukum menunjukkan bahwa usaha ini memerlukan pengawasan terhadap kelengkapan dokumen dan keabsahan dokumen terkait legalitas.

- Analisis aspek sosial, ekonomi dan lingkungan menunjukkan bahwa usaha ini memberikan dampak yang positif terhadap masyarakat pada umumnya.

Berdasarkan analisis terkait aspek non finansial diatas, dapat disimpulkan bahwa usaha produk Tamarillo Yogurt ini layak untuk dijalani serta dikembangkan. Dalam hal aspek keuangan, berdasarkan hasil perhitungan dapat disimpulkan bahwa proyek atau usaha ini memiliki hasil Net Present Value (NPV) sebesar 1,371,150,576, dengan tingkat pengembalian internal (IRR) sebesar 2.69\% dan Net B/C Ratio sebesar 24.57 dimana hasil-hasil tersebut menunjukkan bahwa usaha minuman Tamarillo Yogurt memiliki hasil yang positif.

Selain itu, payback periods dari usaha ini berkisar 1.4 tahun menunjukkan pengembalian modal yang cukup cepat. Oleh karena itu, dari hasil pengukuran finansial ini dapat disimpulkan bahwa usaha minuman Tamarillo Yogurt layak dipertimbangkan karena telah memenuhi keempat standar dari aspek keuangan. Analisis yang terakhir dalam penelitian ini adalah adalah sensitifitas kelayakan usaha, dimana analisis sensitivitas dilakukan dengan menghitung IRR, NPV, B/C ratio dan payback period pada beberapa skenario perubahan harga input atau bahan pokok serta harga jual produk. Berdasarkan pembahasan, dapat disimpulkan bahwa kenaikan bahan baku serta penurunan harga jual akan mempengaruhi nilai investasi usaha Tamarillo Yogurt. Tetapi walaupun begitu, proyek dengan kenaikan harga bahan baku serta penurunan harga jual antara 10 sampai 20 persen masih layak dijalankan.

\section{SARAN}

Melihat manfaat serta keuntungan dari usaha minuman Tamarillo Yogurt ini dapat disimpulkan bahwa usaha tersebut sangat layak untuk dilanjutkan serta dikembangkan, tetapi ada beberapa aspek yang perlu ditingkatkan agar kelangsungan usahanya dapat berjalan lancer serta berkelanjutan. Salah satunya yaitu peningkatan terkait rencana pengembangan produk serta pemasaran. Selain itu aspek manajemen dan organisasi juga penting untuk diperhatikan terutama terbentuknya struktur organisasi yang sesuai bagi usaha ini. Untuk aspek hukum, perlu adanya tindak lanjut terkait legalitas usaha.

Yang terakhir, dalam hal aspek operasional perlu adanya peningkatan kapasitas produksi dengan penambahan tenaga kerja agar dapat mencapai kapasitas maksimum. Dengan begitu, usaha ini dapat mencapai keuntungan yang lebih baik lagi dan bahkan pengembalian modal investasi yang lebih cepat.

\section{DAFTAR PUSTAKA}

Julianto, P.A. (2017, April 5). Perguruan Tinggi Harus Lahirkan Banyak Wirausaha Baru. Kompas, Retrieved from https://ekonomi.kompas.com/read/2017/04 /05/190830426/perguruan.tinggi.harus.lahi rkan. banyak.wirausaha.baru.

Kasmir, Jakfar. (2012). Studi Kelayakan Bisnis. Jakarta: Prenadamedia Group

Nurhidayah, S. (2009). Perbandingan Aktivitas Antioksidan. Retrieved from htttp://lib.ui.ac.id/file?file=digital/123362S09092fkPerbandingan\%20aktivitasLiteratur.pdf 
Purwana, D., Hidayat, N. (2016). Studi Kelayakan Bisnis (Cetakan Pertama). PT Rajagrafindo Persada

Prasetyo, A. (2018, June 5). Rasio Wirausaha Indonesia Sentuh 7\%. Media Indonesia, Retrieved from http://mediaindonesia.com/read/detail/164 639-rasio-wirausaha-indonesia-sentuh-7

Russell, R.S., Taylor, B.W. (2014). Operations Management - Creating Value along the Supply Chain (7th ed.). Wiley.

Sulastri, L. (2016). Studi Kelayakan Bisnis Untuk Wirausaha. LGM - LaGood's Publishing

Sunyoto, D. (2014). Studi Kelayakan Bisnis Bagaimana Menakar Layak atau Tidaknya Suatu Bisnis Dijalankan? (Cetakam Pertama). Center of Academic Publishing Service.

Trott, P. (2008). Innovation Management and New Product Development (6th ed.). England: Pearson Education Limited

Wahyu, A. (2008). Tamarillo nutrition factsand health benefits. (n.d.). Retrieved from http://www.nutrition-andyou.com/tamarillo.html

Zaharuddin, H. (2008). A to Z Entrepreneur in Practice: Business Feasibility Study (1st ed.). Bekasi: CV Dian Anugerah Prakasa. 